\title{
Effects of Cold Storage Environment Change on Antarctic Krill (Euphausia superba) Quality Center
}

\author{
Shuai Chen, Hongliang Huang ${ }^{a,{ }^{*}}$, Xueying Li, Lingzhi Li, Jian Liu, \\ Taichun Qu, Xuefeng Song
}

Key Laboratory of Oceanic and Polar Fisheries, Ministry of Agriculture; East China Sea Fisheries Research Institute, Chinese Academy of Fishery Sciences, Shanghai, 200090, China.

a Corresponding author e-mail: ecshhl@163.com

Keywords: Antarctic krill, quality, Ambient temperature.

\begin{abstract}
In order to deal with the quality of Antarctic krill during the storage and transportation process caused by the failure of the supply system and the freezing equipment in the process of storage and circulation in the form of frozen products, the project team changed the refrigerated environment to the Antarctic The effect of krill quality was studied. When the ambient temperature increased from $-20{ }^{\circ} \mathrm{C}$ to $-12{ }^{\circ} \mathrm{C},-7{ }^{\circ} \mathrm{C},-3{ }^{\circ} \mathrm{C},-1.5{ }^{\circ} \mathrm{C}, 0{ }^{\circ} \mathrm{C}, 1{ }^{\circ} \mathrm{C}, 2.5{ }^{\circ} \mathrm{C}, 4{ }^{\circ} \mathrm{C}, 6{ }^{\circ} \mathrm{C}, 8{ }^{\circ} \mathrm{C}, 12.5{ }^{\circ} \mathrm{C}, 16{ }^{\circ} \mathrm{C}$, the Antarctic krill samples for sensory evaluation, $\mathrm{pH}$ value, the meat rate and soup turbidity and other quality indicators of the determination. The results show that when the ambient temperature from $-20{ }^{\circ} \mathrm{C}$ up to $-1.5{ }^{\circ} \mathrm{C}$ process, the Antarctic krill soup after cooking is more clear, little change in turbidity, $\mathrm{pH}$ quickly increased from 7.60 to 7.85 Antarctic krill muscle elasticity began to change Poor, the sensory quality has begun to change from good to change; when the temperature from $-1.5{ }^{\circ} \mathrm{C}$ to $4{ }^{\circ} \mathrm{C}$, the $\mathrm{pH}$ value slowly increased, there is a certain fluctuation, may be due to differences in the composition of the various components of the decision, Antarctic krill soup after the soup turbidity quickly increased from 0.5 to 0.7 Brix maximum, sensory quality is still at a moderate level; when the temperature rose to $16{ }^{\circ} \mathrm{C}$, the $\mathrm{pH}$ has risen to 8.05 , Antarctic krill Sensory quality from the change into a bad, this time the Antarctic krill has been unable to eat, only as a feed or other use.
\end{abstract}

\section{Introduction}

Due to the distance between the Southern Ocean and the processing technology, most of the Antarctic krill is transported by low temperature on board and transported to the designated location for sale or processing. However, in the storage, circulation process, the power supply system, frozen storage equipment failure caused by storage and transportation process changes in the ambient temperature is not uncommon. But also because of the special mechanism of Antarctic krill quality change mechanism, and endogenous protease in low temperature conditions also have high activity, easily lead to Antarctic krill self-dissolving, black and other quality deterioration. There are scholars at home and abroad to study the different refrigerated or frozen temperature on the Antarctic krill quality changes, but these studies are carried out under constant temperature conditions, and in the experimental production and circulation process, due to equipment failure caused by the environment the temperature of a large fluctuations in the situation also occurred. Therefore, the simulation of power supply or freezing equipment failure and other emergencies, the determination of Antarctic krill sensory quality, $\mathrm{pH}$, turbidity, the rate of meat and other indicators to study the environmental temperature changes on the quality of Antarctic krill, Krill production and circulation process to provide reference data.

\section{Materials and methods}

\subsection{Sensory evaluation.}

The sensory test selected six trained evaluators to form the sensory evaluation group. According to the scoring criteria (Table 1), the color of the Antarctic krill, the body surface, the muscle and the 
5-minute odor and the soup were boiled at $90{ }^{\circ} \mathrm{C}$ For the evaluation of indicators, the indicators out of 10 points, 0 is divided into the worst quality.

Table 1. Antarctic krill sensory test scoring rules

\begin{tabular}{|c|c|c|c|}
\hline Grade & Good ( 7-10 points) & Normal (4-6 points) & Poor (1-3 points) \\
\hline Color & Color normal, glossy & $\begin{array}{l}\text { Color slightly changed, gloss } \\
\text { gradually }\end{array}$ & Dark color dark, dull \\
\hline $\begin{array}{l}\text { Body } \\
\text { surface }\end{array}$ & $\begin{array}{l}\text { Clean and complete, } \\
\text { crustacean, tail no } \\
\text { shedding, no black } \\
\text { phenomenon }\end{array}$ & $\begin{array}{l}\text { More complete individual, a } \\
\text { small number of black-headed } \\
\text { phenomenon but not obvious }\end{array}$ & $\begin{array}{l}\text { Individual incomplete, } \\
\text { crustacean, tail off the } \\
\text { phenomenon of serious } \\
\text { blackhead serious }\end{array}$ \\
\hline Muscle & $\begin{array}{l}\text { Strong muscle tissue, } \\
\text { good elastic tissue }\end{array}$ & $\begin{array}{l}\text { Slightly connected, more } \\
\text { elastic }\end{array}$ & $\begin{array}{l}\text { Hand touch elasticity, tissue } \\
\text { relaxation }\end{array}$ \\
\hline Smell & $\begin{array}{l}\text { The aroma of the } \\
\text { shrimp }\end{array}$ & $\begin{array}{l}\text { Inherent aroma, with a } \\
\text { lighter smell }\end{array}$ & $\begin{array}{l}\text { Strong smell of ammonia } \\
\text { and ammonia }\end{array}$ \\
\hline Soup & $\begin{array}{l}\text { Soup clean with } \\
\text { shrimp color, no meat in } \\
\text { the soup }\end{array}$ & $\begin{array}{l}\text { Soup slightly mixed, Few } \\
\text { organizations fall off in the } \\
\text { soup }\end{array}$ & $\begin{array}{l}\text { Soup is cloudy, fleshy and } \\
\text { corroded and falls off in soup }\end{array}$ \\
\hline
\end{tabular}

\subsection{Determination of $\mathrm{pH}$.}

Take 10 g (wet weight) Antarctic krill, tissue mashed, add $100 \mathrm{~mL}$ of distilled water, immediately with $\mathrm{pH}$ / temperature measuring instrument.

\subsection{Determination of the rate of meat.}

Weigh the individual integrity, no damage to the Antarctic krill 10 g, $90{ }^{\circ} \mathrm{C}$ water bath for 5 min, called the quality of the Antarctic krill M (g), stripped shrimp shell after the quality of Antarctic krill $\mathrm{m}(\mathrm{G})$, into the formula(1) Calculate the meat rate $\left(\mathrm{RM}_{\mathrm{M}}\right)$.

\subsection{Soup of turbidity.}

$$
R_{\mathrm{M}}=\frac{\mathrm{m}}{M} \times 100 \%
$$

5 g Antarctic krill $50 \mathrm{~mL} 90{ }^{\circ} \mathrm{C}$ boiled 5 min after the soup, measured by sugar meter method.

\section{Results}

Antarctic krill quality changes, first manifested in the sensory traits; sensory analysis has a high sensitivity, can perceive a slight deterioration, is a variety of physical and chemical and microbial means irreplaceable; the use of sensory indicators of food quality evaluation, with Simple, intuitive and so on, is an important means to reflect the quality of food. In addition, the color of aquatic products is an important indicator of its quality, shrimp color is the most important factor affecting the purchasing power of consumers. Shrimp body surface contains mainly astaxanthin, hemocyanin, etc., with the storage time, the surface of the astaxanthin gradually oxidized by the oxygen in the air, so that the surface color gradually Green gray becomes gray and black and erythema, freshness drops. The smell of aquatic products is another important factor in the identification of its quality. Freshly caught aquatic products are unique to the fresh smell, but with the decline in freshness, the decomposition and oxidation of the protein in the body will produce irritating amine odor The Therefore, the freshness of aquatic products and the sensory changes are closely related. In the study of the preservation of Antarctic krill in the preservation and preservation of preservatives and vacuum packaging, the same research methods were used. 


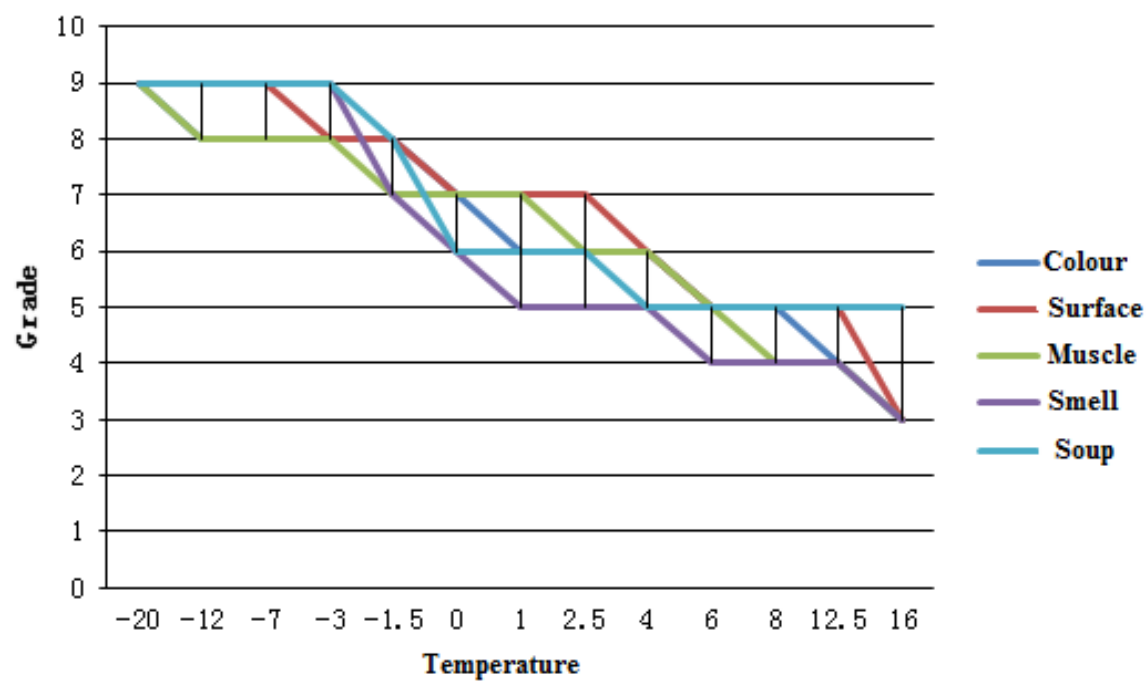

Fig.1 Effect of ambient temperature change on sensory quality of Antarctic krill

Refrigerator after the power outage, the Antarctic krill storage temperature from $-20{ }^{\circ} \mathrm{C}$ quickly rose to $-12{ }^{\circ} \mathrm{C}$, can be seen from Fig.1, at this time Antarctic krill color, body surface, muscle, smell and soup sensory quality changes Very little; temperature rise to $-1.5{ }^{\circ} \mathrm{C}$ when the Antarctic krill color slightly dark, there is a small amount of blackheads, muscle elastic slightly worse, after cooking a little meat hanging in the soup, the sensory quality began to change from When the ambient temperature rises to $16^{\circ} \mathrm{C}$, the sensory score is less than 4 , the Antarctic krill is black, the tissue is loose, the muscle elasticity is deteriorated, the soup becomes turbid after cooking, and the sensory quality becomes poor.

According to the study of Di Qiangan ${ }^{[1]}$, Hang Yujie ${ }^{[2]}$ and so on, Antarctic krill is self-dissolving enzyme, which still has high activity at low temperature, so that protein, amino acid and other decomposition, $\mathrm{pH}$ rise, in this experiment with the temperature 2), the $\mathrm{pH}$ value of Antarctic krill increased, the initial $\mathrm{pH}$ value increased rapidly, then there was a certain fluctuation, but the overall trend was rising, and the $\mathrm{pH}$ value rose from 7.60 to 8.05 at the end of krill corruption. Therefore, the $\mathrm{pH}$ value can be used as an auxiliary indicator of changes in the quality of Antarctic krill.

We can use the sugar meter method to determine the amount of solid content in the soup to quantify the Antarctic krill soup after the turbidity of soup. Antarctic krill samples with the temperature rise, time becomes soft, boiled soup turbidity will have a certain change, as can be seen from Fig. 2, with the temperature rise, Antarctic krill boiled Soup turbidity increases. At the beginning of the temperature rise, there was no meat in the soup and no turbidity. When the temperature rose to $-1.5^{\circ}$ $\mathrm{C}$, the turbidity of the soup increased by 0.1 Brix, which was consistent with the above sensory evaluation of the Antarctic krill. When the temperature rises to $4^{\circ} \mathrm{C}$, the turbidity of the soup reaches a maximum of 0.7 Brix. As the temperature increases, the turbidity of the soup is no longer increased (except $12.5^{\circ} \mathrm{C}$ ), and the sensory score of the Antarctic krill is below 5, To further verify that boiled soup can be used as an effective indicator of changes in sensory quality of Antarctic krill.

Antarctic krill storage process, with the temperature rise, protein loss increased, the rate of meat should be a downward trend, and Fig. 4, the meat rate but showed an increasing trend, which may be due to the short time of the ambient temperature change, Manual peeling, affected by human factors, resulting in the results and experimental design at the beginning of the opposite. 


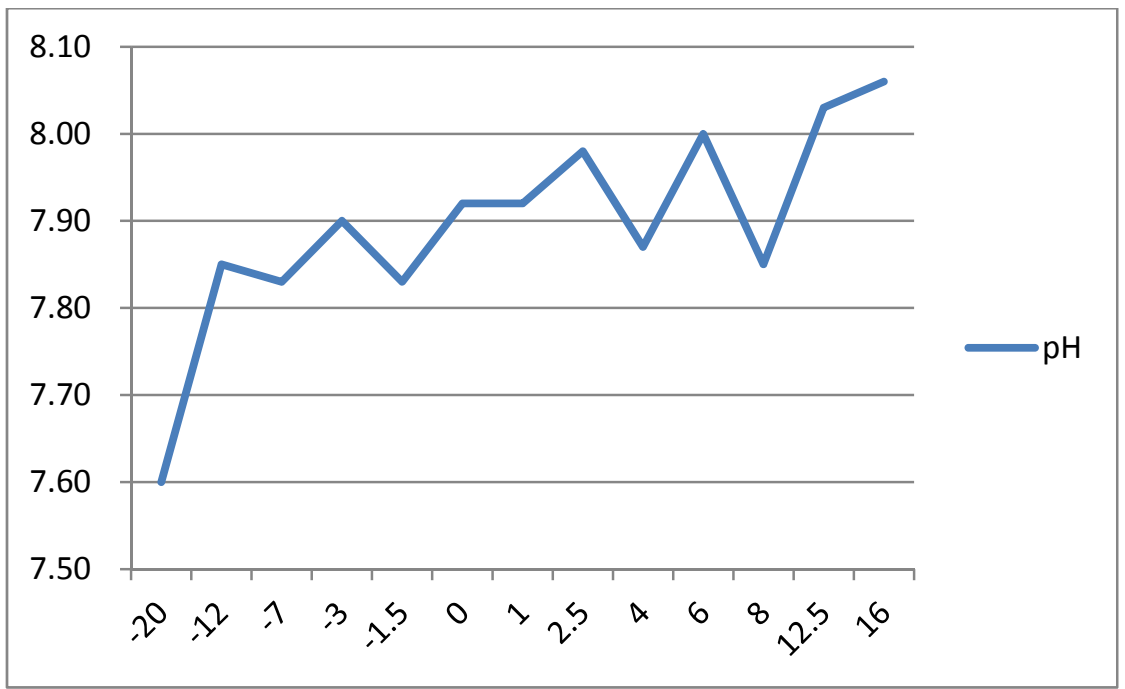

Fig. 2 Effect of ambient temperature on $\mathrm{pH}$ value of Antarctic krill



Fig. 3 Effect of ambient temperature change on turbidity of Antarctic krill soup

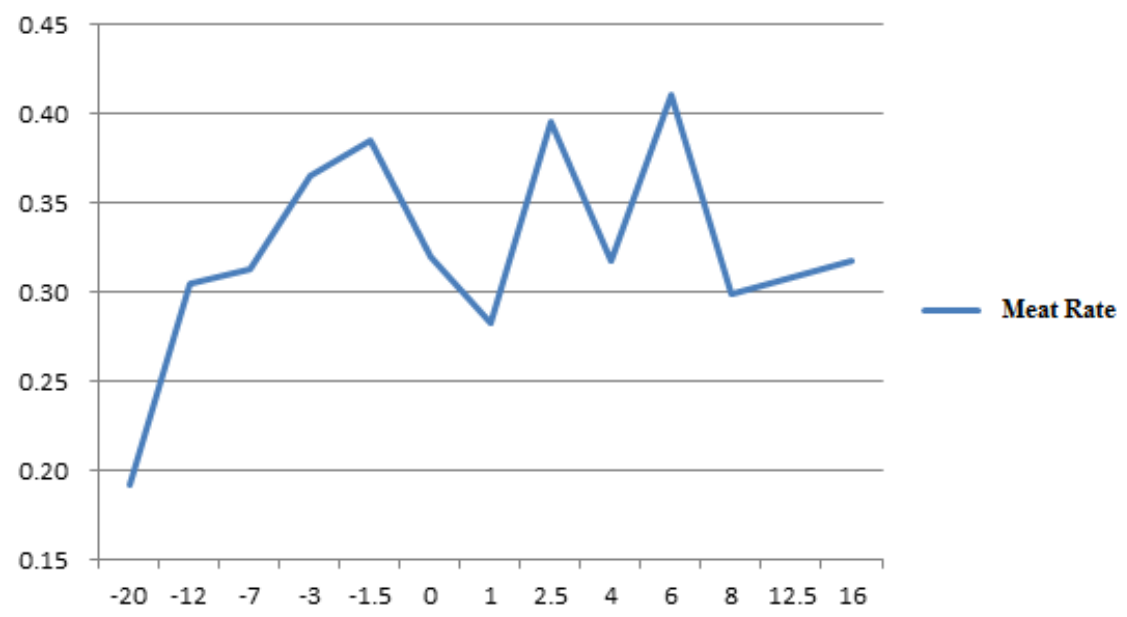

Fig. 4 Effect of environmental temperature change on the meat rate of Antarctic krill

\section{Discussion}

Due to equipment failure caused by the Antarctic krill from the frozen temperature, when the ambient temperature from $-20{ }^{\circ} \mathrm{C}$ increased to $-1.5{ }^{\circ} \mathrm{C}$ process, the Antarctic krill soup after cooking is more clear, little change in turbidity, pH quickly by 7.60 liters Up to 7.85 Antarctic krill muscle elasticity began to deteriorate, the sensory quality has begun to change from good to change; when the temperature from $-1.5{ }^{\circ} \mathrm{C}$ up to $4{ }^{\circ} \mathrm{C}$, the $\mathrm{pH}$ value slowly increased, there is a certain fluctuation may be due to In the case of the difference in the composition of each component, the turbidity of the 
soup of the Antarctic krill was increased rapidly from 0.5 to 0.7 Brix, and the sensory quality was still at a moderate level. When the temperature rose to $16^{\circ} \mathrm{C}$, the $\mathrm{pH}$ The value has risen to 8.05 , the Antarctic krill sensory quality from the change into a bad, this time the Antarctic krill has been unable to eat, can only be used as feed or other. In the rate of meat, the whole process of meat rate change is not, did not appear before the experiment expected experimental phenomenon, it is possible because of the meat rate experiment shrimp shell stripping is carried out manually, subject to human factors , So the experimental results are not obvious.

\section{Acknowledgments}

This work was financially supported by the Special Fund for Agro-scientific Research in the Public Interest of China (No. 201203018), Project NO. 2016T02 Supported by Special Scientific Research Funds for Central Non-profit Institutes （East China Sea Fisheries Research Institute ）, Chinese Polar Environment Comprehensive Investigation and Assessment Program (Grant no. CHINARE2016-0105-07) funded by the State Oceanic Administration of China.

\section{References}

[1]. DI Xiang-qian, BAI Yan-long, TAN Zhao-yi, et al. Research of chilling storage of Antarctic krill (Euphausia superba) Science and Technology of Food Industry. Vol.24 (2012). p. 361-365.

[2]. HANG Yu-jie, LI Xue-ying, YANG Xian-shi, et al. Properties of Autolysis Enzymes from Antarctic Krill, Food Science. Vol.13 (2011). p. 198-200. 